\title{
AKTIVITAS ANTIBAKTERI EKSTRAK ETANOL KULIT DAN BIJI KELENGKENG (Euphoria longan (Lour.) Steud) TERHADAP Escherichia coli DAN Staphylococcus aureus SERTA TOKSISITASNYA TERHADAP Artemia salina Leach
}

\section{ANTIBACTERIAL ACTIVITY ETHANOL EXTRACT OF LONGAN SEED AND PEEL (Euphoria Longan (Lour.) Steud) AGAINST Escherichia coli AND Staphylococcus aureus AND ALSO TOXICITY AGAINST Artemia salina Leach}

\author{
Retno Nur Santi, Muhtadi ${ }^{\star}$, Peni Indrayudha \\ Fakultas Farmasi, Universitas Muhammadiyah Surakarta \\ pmuhtadi@gmail.com
}

\begin{abstract}
ABSTRAK
Berdasarkan penelitian sebelumnya daun, batang, dan cabang kelengkeng Euphoria longan (Lour.) Steud) aktif sebagai antibakteri, antioksidan, dan toksik terhadap Artemia salina Leach. Pada kulit dan biji kelengkeng dilaporkan mengandung senyawa fenolik. Penelitian ini bertujuan untuk mengetahui aktivitas antibakteri ekstrak etanol kulit dan biji kelengkeng terhadap E. coli dan S. aureus, menentukan efek toksik terhadap larva udang Artemia salina L., serta memberikan informasi golongan senyawa yang terkandung dalam ekstrak etanol kulit dan biji kelengkeng.Penelitian ini didahului dengan optimasi penyari etanol 50\%, 70\%, dan 95\%. Kulit dan biji kelengkeng dimaserasi menggunakan penyari etanol 95\% terdestilasi. Ekstrak tersebut digunakan untuk menguji aktivitas antibakteri terhadap E. coli dan S. aureus serta diuji ketoksikannya terhadap Artemia salina L. (Brine Shrimp Lethality Test). Selanjutnya dilakukan kromatografi lapis tipis (KLT) untuk mengetahui kandungan senyawa dari ekstrak etanol kulit dan biji kelengkeng. Bioautografi dilakukan untuk mengetahui senyawa dalam ekstrak yang bertanggung jawab terhadap kematian bakteri uji. Hasil penelitian menunjukkan bahwa ekstrak etanol kulit kelengkeng hingga konsentrasi $4 \%$ belum berpotensi terhadap $\mathrm{E}$. coli dan S. aureus, sedangkan pada ekstrak etanol biji kelengkeng memiliki aktivitas antibakteri terhadap E. coli dan S. aureus dengan KBM berturut-turut sebesar 4\% dan 2\%. Uji ketoksikan ekstrak etanol kulit kelengkeng terhadap Artemia salina $L$. memberikan nilai $L C_{50}$ sebesar $942 \mu \mathrm{g} / \mathrm{mL}$, sedangkan pada ekstrak etanol biji kelengkeng sebesar $3429 \mu \mathrm{g} / \mathrm{mL}$. Hasil KLT menunjukkan bahwa pada ekstrak etanol kulit kelengkeng mengandung senyawa golongan fenolik dan saponin. Sementara dalam ekstrak etanol biji kelengkeng mengandung senyawa golongan fenolik, flavonoid, saponin, dan minyak atsiri. Senyawa pada ekstrak etanol biji kelengkeng yang memiliki aktivitas antibakteri adalah senyawa fenolik dan flavonoid.
\end{abstract}

Kata kunci: Kelengkeng (Euphoria longan (Lour.) Steud), Escherichia coli, Staphylococcus aureus, Brine Shrimp Lethality Test, $K L T$.

\section{ABSTRACT}

Previous research showed that leaves, stems, and branches Euphoria longan (Lour.) Steud active as antibacterial, antioxidant, and toxic to the Artemia salina Leach. Peel and seed of longan was reported contain phenolic compounds. The aims of this research is to determine the antibacterial activity of ethanol extract of the peel and seed of longan to the E. coli and S. aureus, and the toxic effects aqainst shrimp Artemia salina $L$., and also provide information about the class of compounds which is contained in the ethanol extract of the peel and seed of longan. Peel and seed of longan was macerated using 95\% ethanol solvent in the destilation. The extracts were used to test the antibacterial activity to the $\mathrm{E}$. coli and $\mathrm{S}$. aureus as well as toxicity against Artemia salina L (Brine Shrimp Lethality Test). Then performed thin layer chromatography (TLC) to determine the content of compounds from ethanol extract of the peel and seed of longan. Bioautografi conducted to determine the compounds in the extract which is responsible for the death of the test bacteria. The results showed that ethanol extract of peel of longan up to $4 \%$ has no effect to the $\mathrm{E}$. coli and $\mathrm{S}$. aureus. The other hand the ethanol extract of seed longan has antibacterial activity against the $\mathrm{E}$. coli and S. aureus with $\mathrm{MBC} 4 \%$ and $2 \%$ respectively. The ethanol extract of peel and seed of longan could inhibit the larca of Artemia salina Leach with $L C_{50}$ $942 \mathrm{ug} / \mathrm{mL}$ and $3429 \mathrm{ug} / \mathrm{mL}$ respectively. Thin Layer Chromatography analysis showed the ethanol extract of the peel longan contain phenolic compounds and saponins. While the seed ethanol extract group longan contain phenolic compounds, flavonoids, saponins, tanin and essential oils. Flavonoid and phenolic compound of ethanolic extract of seed of longan have potency as antibacterial effect against S.aureus and E.coli.

Key words: Longan (Euphoria longan (Lour.) Steud), Escherichia coli, Staphylococcus aureus, Brine Shrimp Lethality Test, TLC. 


\section{PENDAHULUAN}

Infeksi merupakan masalah penting yang banyak dijumpai pada kehidupan sehari-hari. Penyakit infeksi yang banyak diderita masyarakat di antaranya infeksi Enterobacteria dari golongan Escherichia coli dan infeksi kulit karena Staphylococcus aureus (Anonim, 2004).

Penelitian zat yang berkhasiat sebagai antibakteri perlu dilakukan untuk menemukan produk antimikroba yang berpotensi untuk menghambat dan membunuh bakteri dengan harga yang terjangkau. Alternatif untuk menemukan produk antimikroba adalah dengan memanfaatkan zat aktif yang terkandung dalam tanaman (Widjajanti, 1999).

Berdasarkan hasil beberapa penelitian ilmiah, kulit dan biji kelengkeng memiliki berbagai senyawa kimia. Penelitian Jaitrong et al. (2006) melaporkan bahwa kandungan kimia dalam kulit kelengkeng adalah asam galat, glikosida flavon, dan hidroksinamat dengan kandungan utama flavon berupa kuersetin dan kaemferol. Fraksi eter, kloroform, dan etil asetat daun dan cabang kelengkeng mempunyai aktivitas sebagai antibakteri, antioksidan, dan toksik terhadap Artemia salina L. (metode BST) (Ripa et al., 2010). Ekstrak kloroform batang kelengkeng $\left(100 \mu \mathrm{g} \mathrm{disk}{ }^{-1}\right)$ juga memiliki potensi terhadap jamur Candida albicans dan Aspergillus niger (Rahman et al., 2007).

Soong dan Barlow

(2005) mengemukakan bahwa pada biji kelengkeng mengandung senyawa fenolik seperti corilagin, asam galat, asam ellagat, dan mempunyai senyawa bioaktif. Hal ini diperkuat oleh penelitian Syarifah (2010) yang menyebutkan bahwa minyak dari biji kelengkeng berpotensi sebagai antibakteri terhadap Escherichia coli dengan nilai KHM sebesar 45,74\%.

Berdasarkan penelitian tersebut, tanaman kelengkeng terbukti mempunyai senyawa bioaktif yang dapat dimanfaatkan, terutama pada bagian kulit dan bijinya. Namun sampai saat ini, kulit dan biji kelengkeng belum banyak dimanfaatkan oleh masyarakat dan hanya berakhir sebagai limbah. Oleh karena itu, perlu dilakukan penelitian lebih lanjut terhadap kulit dan biji kelengkeng (Euphoria longan (Lour.) Steud) untuk membuktikan adanya aktivitas antibakteri terhadap Escherichia coli dan Staphylococcus aureus dan uji toksisitas terhadap Artemia salina Leach serta mengetahui golongan senyawa yang terkandung di dalamnya.

\section{METODOLOGI PENELITIAN \\ Alat dan Bahan}

Alat: Alat yang digunakan dalam penelitian ini adalah maserator, vacuum rotary evaporator (Heidolph), inkubator (Memmert), oven (Memmert), bunsen, pipet ukur, mikropipet (Socorex), autoklav (All American), ultrasonik ${ }^{T M}$ (Cleaner), alat timbang (Precisa), bejana kromatografi, lampu UV, flakon, $\mathrm{pH}$ universal, akuarium termodifikasi, lampu, dan alat-alat gelas lainnya (Pyrex).

Bahan: Bahan yang digunakan adalah serbuk kulit dan biji kelengkeng yang diperoleh dari daerah Bandungan, etanol 96\% (teknis) terdestilasi, bakteri E. coli dan $S$. aureus, media $\mathrm{BHI}$ (Brain Heart Infusion) (Oxoid), media $\mathrm{MH}$ (Mueller Hinton) (Merck), DMSO (Dimetilsulfoksida) 2\% dan 2,5\% (teknis), silika gel $\mathrm{GF}_{254}$ (Merck), etanol (pa), kloroform (p.a), metanol (p.a), pereaksi penampak bercak antara lain $\mathrm{FeCl}_{3}$, Liebermann-Burchard (LB), vanilin- $\mathrm{H}_{2} \mathrm{SO}_{4}$, dan sitroborat.

\section{Jalannya Penelitian \\ Determinasi tanaman}

Determinasi tanaman kelengkeng

dilakukan di Laboratorium Biologi Farmasi Fakultas Farmasi Universitas Muhammadiyah Surakarta

\section{Penyiapan tanaman}

Kulit dan biji kelengkeng yang telah terkumpul, dibersihkan dari kotoran menggunakan air bersih yang mengalir. Kemudian dikeringkan di bawah sinar matahari secara tidak langsung dengan ditutupi kain hitam. Selanjutnya kulit dan biji kelengkeng yang telah kering dihaluskan dengan menggunakan blender. Serbuk yang diperoleh kemudian diayak dan ditimbang.

\section{Optimasi Penyari}

Sebanyak 15 gram serbuk kulit dan biji kelengkeng ditimbang dan dimasukan dalam erlenmeyer. Penimbangan ini dilakukan sebanyak tiga kali. Kemudian masing-masing ditambahkan penyari etanol dengan konsentrasi $50 \%$, 70\%, dan $95 \%$ sebanyak 75 $\mathrm{mL}$. Maserasi ini dilakukan selama tiga hari sampai terjadi penjenuhan dilakukan remaserasi sebanyak satu kali. Hasil maserasi yang didapat kemudian diuapkan pelarutnya, dihitung rendemen, dilihat profil kromatografi lapis tipis, dan diuji aktivitas antibakteri terhadap bakteri uji dengan metode Kirby Bauer.

\section{Penyarian}

Metode yang digunakan adalah maserasi. Dari hasil optimasi penyari, dipilih etanol 95\% untuk menyari ekstrak kulit dan biji kelengkeng. Serbuk kulit kelengkeng sebanyak $600 \mathrm{mg}$ dimaserasi dalam $2 \mathrm{~L}$ etanol 95\%(teknis terdestilasi), sedangkan serbuk biji kelengkeng dimaserasi dalam $4 \mathrm{~L}$ etanol $95 \%$ (teknis terdestilasi). Campuran diaduk sampai homogen, didiamkan selama 5 hari dan ditempatkan dalam tempat yang gelap. Hasil maserasi disaring menggunakan corong Buchner. Maserat yang diperoleh ditampung, kemudian diremaserasi sebanyak 1 kali untuk ekstrak kulit kelengkeng dan remaserasi 2 kali untuk ekstrak biji kelengkeng. Maserat 
dievaporasi dengan rotary evaporator dan kandungan air dihilangkan menggunakan waterbath dan vacuum oven dengan menjaga suhunya $<60^{\circ} \mathrm{C}$.

\section{Uji aktivitas antibakteri dengan metode dilusi padat \\ Penviapan sampel. Larutan stok ekstrak} etanol kulit dan biji kelengkeng dibuat sebesar $50 \%$. Pada stok ekstrak kulit kelengkeng dibuat dengan melarutkan 12,5 gram ekstrak kulit kelengkeng dalam $25 \mathrm{~mL}$ DMSO $2 \%$, sedangkan untuk ekstrak etanol biji kelengkeng dilarutkan dalam $25 \mathrm{~mL}$ dalam DMSO 2,5\%. Dari stok $50 \%$ ekstrak kulit kelengkeng tersebut dibuat seri konsentrasi sebesar : 1,25\% b/v; $2,5 \%$ b/v; $5 \%$ b/v; $10 \%$ b/v; dan $20 \%$ b/v. Selanjutnya diambil $1 \mathrm{~mL}$ dari tiap seri konsentrasi tersebut dan ditambah $4 \mathrm{~mL}$ media, sehingga konsentrasi akhir pada tabung menjadi $0,25 \% \mathrm{~b} / \mathrm{v} ; 0,5 \% \mathrm{~b} / \mathrm{v} ; 1 \% \mathrm{~b} / \mathrm{v} ; 2 \% \mathrm{~b} / \mathrm{v}$; dan $4 \% \mathrm{~b} / \mathrm{v}$. Untuk ekstrak biji kelengkeng dibuat seri konsentrasi sebesar $5 \% \mathrm{~b} / \mathrm{v} ; 10 \%$ $\mathrm{b} / \mathrm{v} ; 20 \% \mathrm{~b} / \mathrm{v} ; 30 \% \mathrm{~b} / \mathrm{v}$; dan $40 \%$ b/v. Dari masing-masing seri konsentrasi diambil $1 \mathrm{~mL}$ dan ditambahkan media $4 \mathrm{~mL}$, sehingga konsentrasi akhir pada tabung menjadi $1 \% \mathrm{~b} / \mathrm{v}$; $2 \% \mathrm{~b} / \mathrm{v} ; 4 \% \mathrm{~b} / \mathrm{v} ; 6 \% \mathrm{~b} / \mathrm{v}$; dan $8 \% \mathrm{~b} / \mathrm{v}$. Masingmasing campuran dikocok hingga homogen dan dipadatkan dalam posisi miring.

Pengujian antibakteri. Suspensi bakteri sebanyak $25 \mu \mathrm{L}$ dengan konsentrasi $10^{6}$ $\mathrm{CFU} / \mathrm{mL}$ diratakan pada permukaan campuran ekstrak dan media MH menggunakan ose steril, kemudian diinkubasi selama 18-24 jam. Kontrol yang digunakan terdiri dari tiga macam yaitu kontrol media yang berisi $5 \mathrm{ml}$ media $\mathrm{MH}$, kontrol pelarut yang berisi $4 \mathrm{~mL}$ media $\mathrm{MH}+1$ $\mathrm{mL}$ DMSO $2 \%$ atau $2,5 \%$, dan kontrol bakteri yang berisi $5 \mathrm{~mL}$ media $\mathrm{MH}$.

Penentuan Kadar Bunuh Minimal (KBM). Hasil uji aktivitas antibakteri dari ekstrak etanol kulit dan biji dibandingkan dengan kontrol, yaitu dilihat ada tidaknya pertumbuhan bakteri pada masing-masing tabung. Hasil dikatakan positif (+) jika ada pertumbuhan bakteri, dan hasil negatif (-) jika tidak ada pertumbuhan bakteri. Konsentrasi minimum ekstrak yang masih mampu membunuh bakteri disebut Kadar Bunuh Minimum (KBM).

\section{Uji toksisitas dengan metode Brine Shrimp Lethality Test (BST). \\ Penetasan telur Artemia salina Telur} udang ditetaskan 2 hari sebelum dilakukan uji. Penetasan telur Artemia salina ini dilakukan pada wadah penetasan yang telah terbagi dalam dua bagian, yaitu kompartemen gelap dan kompartemen terang. Kompartemen gelap dibuat dengan menutup semua bagian wadah sehingga tidak ada cahaya yang masuk, sedangkan kompartemen terang ini dibuat dengan penerangan menggunakan lampu belajar dan dalam keadaaan terbuka. Sebagai sekat antara kompartemen gelap dan terang diberi penyekat plastik yang telah dilubangi dengan diameter sekitar $3 \mathrm{~mm}$. Larva yang akan ditetaskan ini ditaruh dalam kompartemen gelap terlebih dahulu. Kemudian larva akan menetas setelah $2 \times 24$ jam. Larva yang sehat akan menuju kompartemen terang karena bersifat fototropi, yaitu mendekati sumber cahaya. Sebelum air laut digunakan, perlu dilakukan pengecekan $\mathrm{pH}$ air laut. Air laut yang baik memiliki $\mathrm{pH}$ antara $\mathrm{pH} 7,3-8,4$.

Penyiapan sampel. Pada uji toksisitas ini dibuat stok sebesar $1 \%$ yaitu sebanyak $500 \mathrm{mg}$ ekstrak kulit dan biji kelengkeng dilarutkan dalam $50 \mathrm{~mL}$ metanol pa. Untuk pengujian BST pada ekstrak kulit kelengkeng ini dibuat seri konsentrasi sebesar 500,1000, 1500, 2000, dan $2500 \mu \mathrm{g} / \mathrm{mL}$ dari stok $1 \%$, sedangkan pada ekstrak biji kelengkeng ini dibuat seri konsentrasi sebesar 2000, 3000, 4000, dan $5000 \mu \mathrm{g} / \mathrm{mL}$ dari stok $1 \%$.

Uji toksisitas. Flakon yang telah disediakan, ke dalamnya di masukkan sampel ekstrak kulit kelengkeng sebanyak $250 \mu \mathrm{L}, 500$ $\mu \mathrm{L}, 750 \mu \mathrm{L}, 1000 \mu \mathrm{L}$, dan $1250 \mu \mathrm{L}$ berturut-turut dari stok $1 \%$. Sedangkan pada ekstrak biji kelengkeng dimasukan sebanyak $1000 \mu \mathrm{L}$, $1500 \mu \mathrm{L}, 2000 \mu \mathrm{L}$, dan $2500 \mu \mathrm{L}$ berturut-turut dari stok $1 \%$. Sebagai kontrol dilakukan cara kerja yang sama, yaitu dengan memasukan 1 $\mathrm{mL}$ pelarut (metanol pa) ke dalam flakon. Kemudian semua flakon diuapkan pada suhu kamar sehingga tidak berbau pelarut. Selanjutnya 10 ekor larva udang Artemia salina L. yang berumur 48 jam dimasukkan dalam masing-masing flakon. Satu tetes suspensi ragi ditambahkan sebagai makanan, kemudian ditambahkan air laut sampai $5 \mathrm{~mL}$. Flakonflakon tersebut diletakan di bawah penerangan selama 24 jam. Uji toksisitas dilakukan 5 kali replikasi.

\section{Identifikasi Senyawa dengan Kromatografi Lapis Tipis (KLT)}

Dibuat larutan uji dengan konsentrasi $5 \%$. Larutan uji ditotolkan pada fase diam silika $\mathrm{GF}_{254}$ sebanyak $2 \mu \mathrm{l}$, setelah totolan kering, kemudian dielusi dengan fase gerak kloroform : metanol (9:1) untuk ekstrak kulit kelengkeng dan kloroform : metanol $(9,5: 0,5)$ untuk ekstrak biji kelengkeng, dan dengan jarak pengembangan $6 \mathrm{~cm}$. Setelah elusi selesai, kromatogram diangkat, dikeringkan, dan dideteksi di bawah sinar $U_{254} \mathrm{~nm}$ dan $U V_{366}$ $\mathrm{nm}$, serta beberapa pereaksi penampak bercak antara lain $\mathrm{FeCl}_{3}$, Liebermann-Burchard (LB), vanilin- $\mathrm{H}_{2} \mathrm{SO}_{4}$, dan sitroborat. Warna yang timbul diamati dan dibandingkan dengan pustaka, serta harga Rf bercak dihitung.

\section{Uji Bioautografi}

Untuk mendeteksi senyawa aktif yang bertanggung jawab terhadap aktivitas 
antibakteri digunakan metode bioautografi dengan cara kromatogram diletakkan pada permukaan media $\mathrm{MH}$ dalam cawan petri yang telah diinokulasi dengan suspensi bakteri sebanyak $100 \quad \mu l$ selama $20 \quad$ menit. Kromatogram diangkat dan selanjutnya media $\mathrm{MH}$ tersebut diinkubasi selama 24 jam pada suhu $37^{\circ} \mathrm{C}$. Bila bercak-bercak pada kromatogram tersebut memiliki aktivitas antibakteri, maka dengan adanya difusi senyawa aktif akan membentuk zona jernih yang merupakan zona hambatan.

\section{HASIL DAN PEMBAHASAN}

Hasil Uji Aktivitas Antibakteri. Uji KBM diperoleh dengan mengamati ada tidaknya pertumbuhan bakteri setelah diinkubasi selama 18-24 jam pada suhu $37^{\circ} \mathrm{C}$. Untuk membantu melarutkan ekstrak etanol kulit kelengkeng digunakan DMSO $2 \%$, sedangkan pada biji kelengkeng digunakan DMSO 2,5\%. DMSO 2\% dan $2,5 \%$ dipilih karena dari pengujian kelarutan ekstrak etanol kulit dan biji kelengkeng terhadap beberapa pelarut dan suspending agent antara lain air, DMSO, dan CMC-Na menunjukan bahwa ekstrak etanol kulit dan biji kelengkeng paling larut dalam DMSO $2 \%$ dan 2,5\%. Konsentrasi ekstrak etanol kulit kelengkeng yang akan diuji adalah $0,5 \%$; $1 \%$; $2 \%$; $4 \%$; dan 6\%. Dan pada biji kelengkeng seri konsentrasi yang diuji adalah $1 \%$; $2 \%$; 4\%; 6\%; dan $8 \%$ Hasil uji aktivitas antibakteri ekstrak etanol kulit dan biji kelengkeng terhadap $E$. coli dan $S$. aureus dapat dilihat di Tabel 1 dan 2.
Kulit dan biji kelengkeng mengandung flavonoid yang merupakan senyawa fenol (Harborne, 1987). Menurut Dwidjoseputro (1994) senyawa fenol dapat bersifat sebagai koagulator protein. Flavonoid berfungsi sebagai antibakteri dengan cara membentuk senyawa kompleks terhadap protein ektraseluler yang mengganggu integritas membran sel bakteri. Mirzoeva et al. (1997) cit Sabir (2005) dalam penelitiannya mendapatkan bahwa flavonoid mampu melepaskan energi tranduksi terhadap membran sitoplasma bakteri dan menghambat motilitas bakteri. Mekanisme yang berbeda dikemukakan oleh Di Carlo et al. (1999) dan Estrela et al. (1995) cit Sabir (2005) yang menyatakan bahwa gugus hidroksil yang terdapat pada struktur senyawa flavonoid menyebabkan perubahan komponen organik dan transpor nutrisi yang akhirnya akan mengakibatkan timbulnya efek toksik terhadap bakteri.

Selain flavonoid, pada biji kelengkeng terdapat tanin dan saponin. Tanin memiliki aktivitas antibakteri. Secara garis besar mekanisme yang diperkirakan yaitu tanin dapat merusak membran sel bakteri. Senyawa astringent tanin dapat menginduksi pembentukan kompleks senyawa ikatan terhadap enzim atau substrat mikroba dan pembentukan suatu kompleks ikatan tanin terhadap ion logam yang dapat menambah daya toksisitas tanin itu sendiri (Akiyama et al., 2007 cit Juliantina et al., 2008).

Tabel 3- Hasil uji aktivitas antibakteri ekstrak etanol kulit kelengkeng terhadap E. coli dan S. aureus

\begin{tabular}{|c|c|c|c|c|c|c|c|}
\hline \multicolumn{4}{|c|}{ E.coli } & \multicolumn{4}{|c|}{ S.aureus } \\
\hline $\begin{array}{c}\text { Konsentrasi } \\
(\% \text { b/v) }\end{array}$ & \multicolumn{3}{|c|}{ Pengujian } & $\begin{array}{c}\text { Konsentrasi } \\
(\% \mathrm{~b} / \mathrm{v})\end{array}$ & \multicolumn{3}{|c|}{ Pengujian } \\
\hline 0,25 & ++++ & ++++ & ++++ & 0,25 & ++++ & ++++ & ++++ \\
\hline 1 & ++++ & ++++ & ++++ & 1 & ++++ & ++++ & ++++ \\
\hline 2 & ++++ & +++ & +++ & 2 & +++ & +++ & +++ \\
\hline 4 & +++ & +++ & +++ & 4 & +++ & +++ & +++ \\
\hline K3 & - & - & - & K3 & - & - & - \\
\hline
\end{tabular}

Tabel 4- Hasil uji aktivitas antibakteri akstrak etanol biji kelengkeng terhadap E. coli dan S. aureus

\begin{tabular}{|c|c|c|c|c|c|c|c|}
\hline \multirow{2}{*}{$\begin{array}{c}\text { Konsentrasi } \\
(\% \mathrm{~b} / \mathrm{v})\end{array}$} & \multicolumn{3}{|c|}{ E.coli } & \multicolumn{4}{|c|}{ S.aureus } \\
\hline & & engujia & & $\begin{array}{l}\text { Konsentrasi } \\
(\% \text { b/v) }\end{array}$ & \multicolumn{3}{|c|}{ Pengujian } \\
\hline 1 & ++ & ++ & ++ & 1 & + & + & + \\
\hline 4 & - & - & - & 4 & - & - & - \\
\hline 6 & - & - & - & 6 & - & - & - \\
\hline 8 & - & - & - & 8 & - & - & - \\
\hline K3 & - & - & - & K3 & - & - & - \\
\hline
\end{tabular}

\footnotetext{
Keterangan:

(+) : Terdapat pertumbuhan bakteri

$(-) \quad$ : Tidak terdapat pertumbuhan bakteri

K1 : Kontrol pelarut ( $4 \mathrm{~mL}$ media $\mathrm{MH}+1 \mathrm{~mL} \quad \mathrm{DMSO}+50 \mu \mathrm{l}$ suspensi bakteri)

$\mathrm{K} 2$ : Kontrol bakteri ( $5 \mathrm{ml}$ media $\mathrm{MH}+50 \mu \mathrm{L}$ suspensi bakteri)

K3 : Kontrol media (5 ml media $\mathrm{MH})$
} 
Hasil Uji Toksisitas. Metode yang digunakan dalam pengujian toksisitas ini adalah metode Brine Shrimp Lethality Test (BST). Metode BST merupakan suatu metode untuk menentukan toksisitas suatu senyawa atau ekstrak secara akut dengan menggunakan hewan coba Artemia salina Leach. Analisis hasil ditentukan dengan nilai $\mathrm{LC}_{50}$. Nilai $\mathrm{LC}_{50}$ merupakan konsentrasi dimana zat menyebabkan kematian $50 \%$ yang diperoleh dengan memakai persamaan regresi linier $\mathrm{y}=\mathrm{a}$ + bx. Suatu zat dikatakan aktif atau toksik bila nilai $\mathrm{LC}_{50}<1000 \mu \mathrm{g} / \mathrm{mL}$ untuk ekstrak dan $<30$ $\mu \mathrm{g} / \mathrm{mL}$ untuk suatu senyawa.

Berdasarkan perhitungan data yang diperoleh, diketahui nilai $\mathrm{LC}_{50}$ untuk ekstrak etanol 95\% kulit kelengkeng adalah sebesar $942 \mu \mathrm{g} / \mathrm{mL}$ (Tabel 3). Hal ini menunjukkan bahwa ekstrak etanol 95\% kulit kelengkeng memiliki senyawa aktif tertentu yang toksik terhadap larva Artemia salina Leach, namun dengan potensi yang lemah. Profil KLT pada ekstrak etanol 95\% kulit kelengkeng menunjukkan bahwa terdapat dua bercak yang terlihat jelas berfluoresensi pada $U V_{366}$, yaitu pada hRf 16 dan 90. Pada hRf 16 dan 90 dimungkinkan adalah senyawa saponin dan fenolik. Senyawa ini diprediksi dapat menyebabkan ketoksikan pada Artemia salina Leach. Dalam penelitian Juniarti dkk. (2009) menyebutkan bahwa senyawa yang bersifat toksik adalah seyawa yang tersari pada pelarut yang bersifat polar. Sehingga sifat toksik dari ekstrak etanol 95\% kulit kelengkeng diperkirakan disebabkan oleh kandungan senyawa polar yang terdapat di dalamnya seperti saponin dan fenolik.

Nilai LC $_{50}$ ekstrak etanol $95 \%$ biji kelengkeng sebesar $3429 \mu \mathrm{g} / \mathrm{mL}$ (Tabel 4). Nilai LC $_{50}$ tersebut menunjukkan bahwa senyawa pada ekstrak etanol 95\% biji kelengkeng kurang toksik terhadap larva Artemia salina Leach. Dalam profil KLT ekstrak etanol $95 \%$ biji kelengkeng menunjukkan bahwa pada hRf 88 terlihat jelas berfluoresensi pada $\mathrm{UV}_{366}$. Pada $\mathrm{hRf}$ tersebut diprediksi merupakan senyawa minyak atsiri. Senyawa ini diduga penyebab ketoksikan pada Artemia salina Leach. Namun berdasarkan hasil uji ketoksikan ini, dimungkinkan senyawa tersebut kurang poten atau kurang toksik terhadap Artemia salina L. Sehingga untuk membunuh 50\% larva Artemia salina pada uji ini diperlukan konsentrasi ekstrak etanol $95 \%$ biji yang lebih besar yaitu $3429 \mu \mathrm{g} / \mathrm{mL}$.

Hasil Analisis Kromatografi Lapis Tipis. Pemeriksaan kandungan kimia secara kromatografi lapis tipis (KLT) dilakukan untuk mengetahui kandungan senyawa yang terdapat dalam ekstrak etanol kulit dan biji kelengkeng. KLT dilakukan dengan menggunakan fase diam silika gel $\mathrm{GF}_{254}$. Uji pendahuluan KLT dilakukan untuk mencari fase gerak yang tepat agar pemisahannya baik. Dari hasil pendahuluan dengan mencoba beberapa fase gerak dengan berbagai perbandingan, diperoleh bahwa kloroform : metanol (9:1) v/v memberikan hasil pemisahan yang terbaik untuk ekstrak kulit kelengkeng dan kloroform : metanol $(9,5: 0,5)$ $\mathrm{v} / \mathrm{v}$ untuk ekstrak biji kelengkeng, sehingga dalam uji bioautografi dan analisis KLT digunakan fase gerak tersebut.

Analisis KLT dilakukan terhadap golongan senyawa yang terdapat dalam ekstrak etanol kulit dan biji kelengkeng. Adapun golongan senyawa yang akan dideteksi adalah fenolik, saponin, minyak atsiri, dan flavonoid. Hasil KLT dideteksi dengan sinar $U V_{254 n m}$ dan $U V_{366 n m}$, serta beberapa pereaksi penampak bercak antara lain $\mathrm{FeCl}_{3}$, Liebermann-Burchard (LB), vanilin- $\mathrm{H}_{2} \mathrm{SO}_{4}$, dan sitroborat. Dari hasil analisis KLT menunjukkan ekstrak etanol 95\% kulit kelengkeng menunjukkan adanya spot yang mengandung senyawa golongan fenolik dan saponin. Pada ekstrak etanol 95\% biji kelengkeng menunjukkan adanya senyawa golongan fenolik, flavonoid, saponin, dan minyak atsiri.

Tabel - 3. Perhitungan $\mathrm{LC}_{50}$ ekstrak etanol $95 \%$ kulit kelengkeng (Euphoria longan (Lour.) Steud) terhadap Artemia salina Leach

\begin{tabular}{cccccc}
\hline Konsentrasi & Log Konsentrasi & \% Kematian rata-rata & Angka probit $(\mathrm{y})$ & $\begin{array}{c}\text { Hasil Regresi } \\
\text { Linier }\end{array}$ & LC $_{50}$ \\
\hline 0,050 & $-1,30$ & 24 & 4,29 & & \\
0,100 & -1 & 46 & 4,90 & a: 8,447 & \\
0,150 & $-0,82$ & 50 & 5 & b: 3,361 & $942 \mu \mathrm{g} / \mathrm{mL}$ \\
0,200 & $-0,7$ & 86 & 6,08 & r: 0,9602 & \\
0,250 & $-0,6$ & 96 & 6,75 & & \\
\hline
\end{tabular}

Tabel - 4. Perhitungan $\mathrm{LC}_{50}$ ekstrak etanol 95\% biji kelengkeng (Euphoria longan (Lour.) Steud) terhadap Artemia salina Leach

\begin{tabular}{cccccc}
\hline Konsentrasi & Log Konsentrasi & $\begin{array}{c}\text { \% Kematian } \\
\text { rata-rata }\end{array}$ & $\begin{array}{c}\text { Angka probit } \\
(\mathrm{y})\end{array}$ & $\begin{array}{c}\text { Hasil Regresi } \\
\text { Linier }\end{array}$ & LC $_{50}$ \\
\hline 0,200 & $-0,69$ & 0 & 0 & a: 15,684 & \\
0,300 & $-0,52$ & 20 & 4,16 & b: 22,988 & $3429 \mu \mathrm{g} / \mathrm{mL}$ \\
0,400 & $-0,39$ & 46 & 4,90 & r: 0,949 & \\
0,500 & $-0,30$ & 100 & 10 & \\
\hline
\end{tabular}


Hasil Uji Bioautografi. Uji bioautografi dilakukan untuk mengetahui golongan senyawa yang terkandung dalam ekstrak etanol biji kelengkeng yang dapat menghambat pertumbuhan bakteri. Penotolan sampel (ekstrak etanol biji kelengkeng) pada lempeng silika gel GF $_{254 n m}$ sebanyak $2 \mu$ yaitu 1 totolan. Lempeng kromatogram diletakkan di atas media $\mathrm{MH}$ yang telah diinokulasi dengan suspensi bakteri selama 20 menit dengan tujuan agar senyawa-senyawa kimia terpisah berupa bercak-bercak pada kromatogram dapat berdifusi pada lapisan media MH. Bila bercakbercak memiliki aktivitas antibakteri, maka dengan adanya difusi tersebut akan terbentuk zona jernih yang merupakan zona hambatan senyawa kimia dari ekstrak etanol biji kelengkeng.

Hasil uji bioautografi ekstrak etanol biji kelengkeng menunjukkan adanya zona jernih pada media $\mathrm{MH}$ yang mengandung $S$. aureus. Bila dilihat pada media $\mathrm{MH}$ pertumbuhan $S$. aureus pada hRf 4 , yang diprediksi merupakan senyawa golongan fenolik dan flavonoid. Pada media yang mengandung $E$. coli, terlihat adanya zona hambat pada hRf 4, yang dimungkinkan adalah senyawa golongan fenolik dan flavonoid. Sehingga dapat disimpulkan bahwa komponen golongan senyawa dari ekstrak etanol biji kelengkeng yang memiliki aktivitas antibakteri terhadap bakteri $S$. aureus dan $E$. coli kemungkinan merupakan senyawa golongan fenolik dan flavonoid.

Diketahui bahwa flavonoid yang merupakan golongan senyawa fenol (Harborne, 1987) bekerja dengan cara mendenaturasi protein sel dan merusak membran sel bakteri. Suatu substansi yang dapat merusak sel tanpa dapat diperbaiki kembali (irreversible) sehingga pertumbuhan bakteri terhambat (Pelczar dan Chan, 1988).

Senyawa golongan fenolik dan flavonoid juga dimungkinkan memiliki aktivitas terhadap
Artemia salina Leach. Meskipun kurang aktif, potensi dari golongan flavoniod dan fenol patut diteliti lebih dalam untuk mengetahui aktivitasnya lebih lanjut. Dilakukannya fraksinasi dan pengujian ke aktivitas yang lain perlu dilakukan untuk menambah data ilmiah tentang potensi kulit dan biji kelengkeng.

\section{KESIMPULAN}

Berdasarkan hasil penelitian yang telah diperoleh, maka dapat disimpulkan bahwa ekstrak etanol 95\% kulit kelengkeng hingga konsetrasi $4 \%$ belum menunjukkan potensi antibakteri terhadap bakteri $E$. coli dan $S$. aureus, sedangkan ekstrak etanol 95\% biji kelengkeng memiliki aktivitas antibakteri terhadap $E$. coli dengan nilai KBM $4 \%$ dan $S$. aureus dengan nilai KBM $2 \%$.

Ekstrak etanol 95\% kulit kelengkeng memiliki toksisitas terhadap Artemia salina Leach dengan nilai $\mathrm{LC}_{50}$ sebesar $942 \mu \mathrm{g} / \mathrm{mL}$, sedangkan ekstrak etanol 95\% biji kelengkeng memiliki toksisitas terhadap Artemia salina L. dengan nilai $\mathrm{LC}_{50}$ sebesar $3429 \mu \mathrm{g} / \mathrm{mL}$.

Profil KLT untuk etanol 95\% kulit kelengkeng menunjukkan adanya spot yang mengandung senyawa golongan fenolik dan saponin. Pada ekstrak etanol 95\% biji kelengkeng menunjukkan adanya senyawa golongan fenolik, flavonoid, saponin, dan minyak atsiri. Senyawa pada ekstrak etanol 95\% biji kelengkeng yang memiliki aktivitas antibakteri terhadap E.coli dan $S$. aureus adalah senyawa flavonoid.

\section{SARAN}

Perlu dilakukan fraksinasi dan uji senyawa aktif dari ekstrak etanol 95\% biji kelengkeng terhadap bakteri E.coli dan $S$. aureus multiresisten antibiotik serta aktivitas antijamur dan antioksidan yang lebih berpotensi.

\section{DAFTAR PUSTAKA}

Akiyama, H., Fujii, K., Yamasaki, O., Oono, T., Iwatsuki, T., 2001, Antibacterial Action of Several Tannins Agains Staphylococcus aureus, Journal of Antimicrobial Chemotherapy, 48, 487-91.

Anonim, 2004, Infeksi Enterobacteria, (online), (www.medicastore.com, diakses 3 Maret 2010).

Carlo, Di, Mascolo N., Izzo, A. A., Capasso, F., 1999, Flavonoids: old and new aspects of a class of natural therapeutic drugs, Life Science, 65 (4), 53-337.

Harborne, J. B., 1996, Metode Fitokimia Penuntun Cara Modern Menganalisis Tumbuhan, diterjemahkan oleh Padmawinata, K., dan Soediro, Penerbit ITB, Bandung.

Hendrawati, A. R., 2009, Uji Toksisitas Akut Ekstrak Etanol Daun Kemangi, Skripsi, Fakultas Kedokteran Universitas Diponegoro, Semarang. 
Jaitrong, S., Nithiya R. and John A. M., 2006, Analysis of The Phenolic Compounds in Longan (Euphoria longan Lour. Steud) Peel, Journal, (online),(http://www.agro.cmu.ac.th/Research/WebAjarn/ppp/nr_0062.pdf, diakses tanggal 3 Maret 2010).

Juniarti, Delvi O., Yuhernita, 2009, Kandungan Senyawa Kimia, Uji Toksisitas (Brine Shrimp Lethality Test) dan Antioksidan (1,1-diphenyl-2-pikrilhydrazy) dari Ekstrak Daun Saga (Abrus precatorius L.), Journal, (online), (http://journal.ui.ac.id/upload/artikel/10_Edit 1_JUNIARTI_KANDUNGAN\%20SENYAWA\%20KIMIA_Layout.pdf, diakses tanggal 25 Desember 2010).

Mirzoeva, O. K., Grishanin, R. N., Calder, P. C., 1997, Antimicrobial action of propolis and some of its components: the effects on growth, membrane potential, and motility of bacteria, Brazilian Journal of Microbioloy, 152, 239-46.

Pelczar, M. J. dan Chan, E. C. S., 1988, Dasar-Dasar Mikrobiologi, diterjemahkan oleh Hadioetomo, R. S., Penerbit Universitas Indonesia, Jakarta.

Rahman, K. M., Kamrun, N., Mohammad, G. U. K., Choudhury, M. H., 2007, Phytochemical and Biological Studies on Nephelium longan, Boletin Latinoamericano y del Caribe de Plants Madicinales y Aromaticans, 6 (3), 68-72, (online), (http://redalyc.uaemex.mx/pdf/856/85660305.pdf, diakses tanggal 25 Desember 2010).

Ripa, F. A., Haque, M. and Bulbul, I. J., 2010, In Vitro Antibacterial, Cytotoxic and Antioxidant Activities of Plant Nephelium longan, Pak J. Biol. Sciences, 13: 22-27, (online), (http://scialert.net/qredirect, diakses tanggal 3 Maret 2010).

Sabir, A., 2005, Aktivitas Antibakteri Flavonoid Propolis Trigona sp terhadap Bakteri Streptococcus mutans (in vitro), Majalah Kedokteran Gigi (Dent. J.), 58 (3), 135-141.

Soong, Y. Y. and Philip John Barlow, 2005, Isolation and Structure Elucidation of Phenolic Compounds from longan (Euphoria longan Lour. Steud.) seed by High-Performance Liquid Chromatography-Electrospray Ionization Mass Spectrometry, Journal, (online), (http://www.sciencedirect.com, diakses tanggal 20 Maret 2010).

Syarifah, M., 2010, Isolasi, Karakterisasi, dan Uji Aktivitas Antibakteri Minyak Biji Buah Kelengkeng Lokal dan Impor serta Identifikasi Asam Lemak Penyusunnya, Skripsi, Jurusan Kimia, Fakultas MIPA, Universitas Negeri Malang, Malang.

Widjayanti, V. N., 1999, Obat-obatan, Penerbit Kanisius, Yogyakarta. 